\title{
Случай на туларемия с нетипично протичане в УНГ-практика
}

\author{
Д. Конова \\ УМБАЛ „Царица Йоанна - ИСУЛ“ ЕАД - София
}

\section{Резюме}

Предмет на изследването е случай с тежьк некротизиращ грануломатозен лимфаденит. Приложихме оперативно лечение (Dissectio coli sinistra) и бяхме насочени от патолога за изследвания, с които доказахме нетипичен случай на туларемия. Причинителят Pasturela tularensis (от рода Franciella, семейството на Brucellaceae) се предава от насекоми, като основен резервоар са гризачите (,заешка треска“). Хората се заразяват чрез ухапване, храна, вдишване, пряк контакт - винаги се открива „входна врата“ на инфекцията. В този случай такава не установихме, както и висока температура (треска). Заболяването се демонстрира и с много по-дълъг инкубационен период. Тази нетипичност маскира заболяването, поради което ние приехме болния по неотложност.

Ключови думи: Туларемия, нетипичен случай, неотложност

\section{Въведение}

Туларемията е инфекциозно заболяване, причинено от бактерия (Francisella tularensis - тип А и тип В). Предава се чрез ухапване от кърлежи, комари, като основен резервоар са гризачите (плъхове, зайци), порядко птици, котки и кучета.

Нарича се „заешка треска“ и протича остро.

Човек се заразява чрез храната, ухапване, вдишване и в пряк контакт с човешката кожа и лигавици.

Клинични форми:

- лимфоидната (или бубонна) форма се проявява чрез увеличени регионални или генерализирани лимфни възли;

- ангинозната форма симулира ангина, проявяваща се с улцеро-некротичен трудно отделящ се налеп от тонзиларната тъкан;

- очна и стомашна форми не попадат при оториноларинголога;

- най-тежката е белодробната форма, проявяваща се с неповлияваща се от стандартно лечение рецидивираща бронхопневмония.

\section{Цел}

Целта на изследването е да покажем нетипичен случай на туларемия, като проявлението му без треска, без установяване на „входна врата“, нетипичен инкубационен период на фона на добро общо състояние може да заблуди клинициста.

\section{Материал и метод}

Методиките, които използвахме са следните: 
$\checkmark$ анамнеза;

- оториноларингологичен преглед (оромезофарингоскопия, индиректна и директна задна риноскопия, ларингоскопия и хипофарингоскопия);

- образна диагностика (компютър томография и рентгенография);

- ехография;

- кръвни изследвания;

- патохистологично изследване на отстранения по оперативен път лимфен пакет (ex juvantibus);

- серологично изследване;

- откриване на антитела в кръвни проби (ELISA и FА тестове);

От нашия опит представяме случай, протекъл нетипично. Касае се за 22-годишен мъж (М.Д.К. - ИЗ - 5873/03.2010 г.)

\section{От анамнезата:}

Болният съобщава, че през месец декември 2009 г. е бил контактен с пльхове и диви зайци в чужбина (европейска страна). В началото на 2010 г. се поя- вила подутина вляво на шията, която нараствала леко, докато в последната седмица (март 2010 г.) рязко нараснала, появили се и други по-дребни подутини.

\section{От локалния статус:}

Пакет увеличени 6/6 см лимфни възли вляво на шията, горната трета на MSCM sin. с тестовидна консистенция, неболезнени, несраснали и единични такива по хода на vena jugularis sinistra. Останалият детайлен УНГ-статус (чрез директни и индиректни изследвания на устна кухина, фаринкс, ларинкс и трахея) не показа патологични промени.

Добро общо състояние, няма редукция на тегло, оргономегалия, температура и обриви.

Крьвни показатели: лимфопения и леко покачване на общия билирубин.

Ехографията на коремни органи не показва патологични промени.

Компютърна томография: потвърди обективната находка на шията.

Рентгенография на бял дроб: без патологични промени.
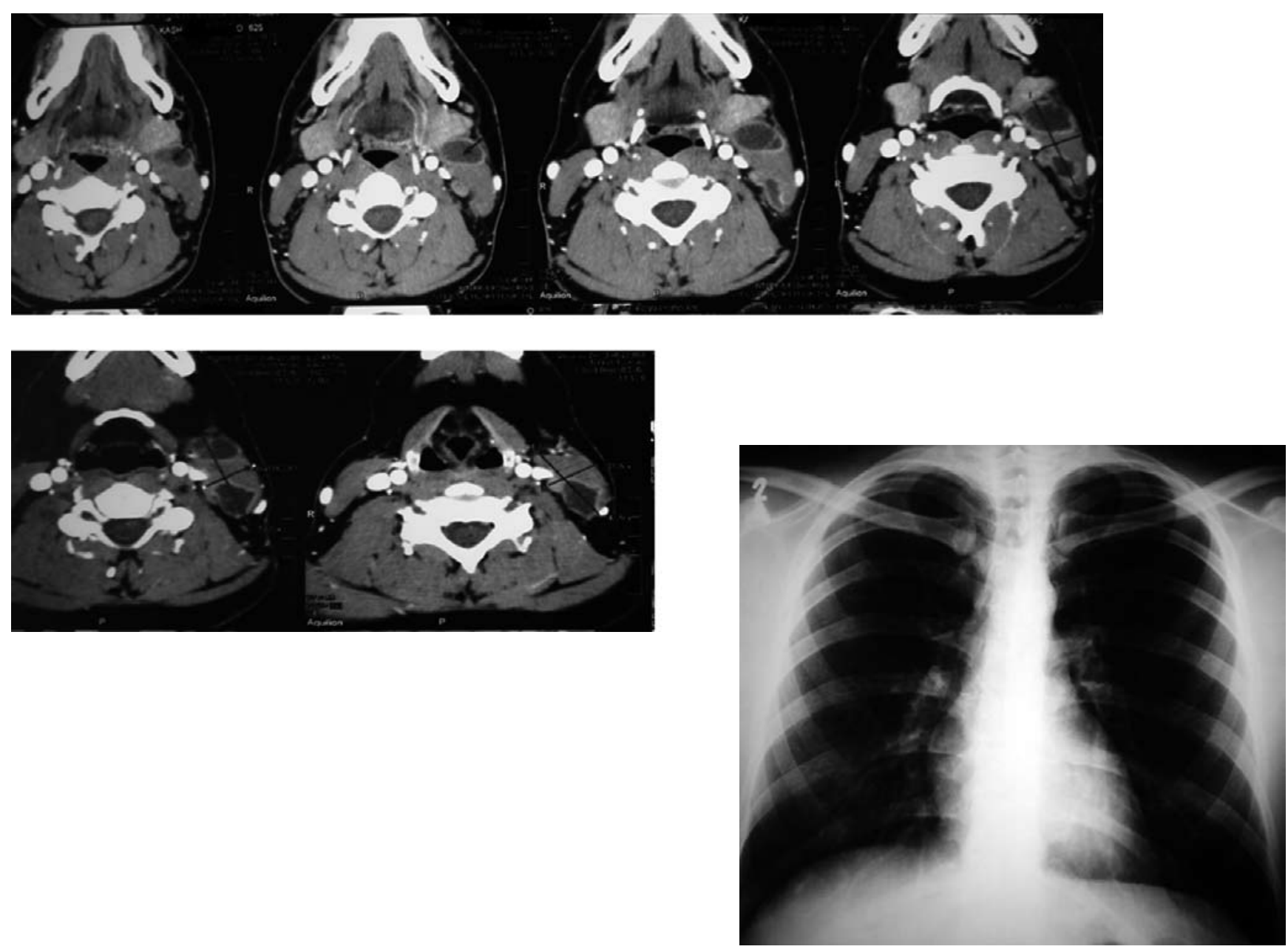


\section{Методи за поставяне на диагнозата}

1. На клинична конференция се прие, че се касае най-вероятно за пациент със системно заболяване, изискващо неотложно оперативно лечение с патохистологична верификация на проблема.

Под обща интубационна анестезия се направи Dissectio conservative coli sinistra. От II зона отстранихме два лимфни възела с размер $2 / 3 \mathrm{~cm}$, от III зона - един $6 / 6$ см - тумор в разпад и пробита капсула, като инфилтрира съседните меки тъкани. Отстранихме целия лимфен басейн, като отделихме единични, уголемени в различна степен лимфни възли. Макроскопски установихме тъмен некротичен център при всички лимфни възли. Нормални оперативен и следоперативен периоди на фона на антибиотична защита. Операционната рана зарасна per primam.

2. Патохистологичното изследване показа, че се касае за некротизиращ грануломатозен лимфаденит, картина, суспектна за туларемия.

3. Направихме серологично изследване РНХА - степенна аглутинация тип Видал, BD - 1: 640, $\mathrm{BD}-1: 320$. Доказахме туларемия и насочихме пациента към инфекциозна болница за продължаване на лечението.

\section{Диференциална диагноза}

- лимфоми

- тумори

- метастази

- абсцеси

- паразитози

- туберкулоза, луес

- имунодефицитни заболявания и др.

\section{Лечение}

- оперативно

- консервативно (от инфекционист)

\section{Прогноза}

Пълно излекуване, като се прилага продължително антибиотично (хинолони и аминогликозиди) лечение. След преболедуване остава траен имунитет, при някои професии може да се приложи ваксинация.

Някои автори декларират 1\% смъртност предимно при белодробните форми и такива, усложнени от специфичен сепсис.

\section{Заключение}

При така представения случай установихме следното:

- дъльг инкубационен период;

- липсва „входна врата“ на проникване;

- липса на треска (температура);

- подостро протичане;

- добро общо състояние;

Туларемията като инфекциозно заболяване може да протече нетипично и да симулира редица заболявания. Това може да заблуди клиницистите, независимо от големия обем на предоперативни изследвания. В тези случаи ние категорично заставаме зад оперативното лечение по неотложност. Това поведение предотвратява дисеминацията на процеса. Крайната диагноза е в резултат на общите усилия на патолози, имунолози и клиницисти.

\section{Литература:}

1. Р. Комитова, П. Петров, Т. Кантарджиев, Р. Ненова, Б. Попов, И. Иванов, Л. Панчев, А. Николова, Ц. Георгиева, М. Русинова, М. Борисова, Е. Бадаланова и Пл. Падешки, Медицински преглед. Туларемия в България - 2003-2004 г. - 44, 2008, № 3, 45-50.
2. Ryan KJ, Ray CG (editors) (2004). Sherris Medical Microbiology (4th ed.). McGraw Hill. pp. 488-90.

3. Jellison WL, Owen C, Bell JF, Kohls GM (1961). "Tularemia and animal populations“. Wildl Dis 17: 1-22. 